\title{
ОБГРУНТУВАННЯ КАНАЛУ ЕЛЕКТРОПОСТАЧАННЯ НА ОСНОВІ ГАЗОГЕНЕРАТОРНОЇ УСТАНОВКИ
}

\author{
О.Ф. Соколовський, канд. техн. наук, Я.Д. Ярош, канд. техн. наук, \\ Н.М. Цивенкова, канд. техн. наук, С.М. Кухарець, докт. техн. наук \\ Житомирський національний агроекологічний університет \\ 10008 Старий бульвар, 7, м. Житомир
}

Сучасною тендениією розвитку енергетики є прагнення до збалансованості енергетичного комплексу, підвищення надійно-
сті електропостачання споживачів. Важливе місие в стратегії розвитку електроенергетики займають автономні систе-
ми електропостачання. Вони використовуються на підприємствах, в аеро-, морських і річкових портах, в енергоблоках
лікарень, у фермерських господарствах, в системах аварійного енергопостачання, на об'єктах оборонного комплексу -
скрізь, де потрібна електроенергія, в той час як мережа або віддалена, або працњює перебоями.
Представлено автономну систему енергопостачання з двигунами внутрішнього згорання. Основним перетворювачем ме-
ханічної енергї приводних двигунів в електричну є електромехнічний перетворювач змінного струму з обмоткою ханічної енергї приводних двигунів в
збудження, яка розташована на роторі.

Представлено алгоритм, згідно з яким на початку ииклу контролер визначає добову норму спожсивання електроенергії та, відповідно до типу дня і часу доби, виконує дії за коротким чи розгалуженим алгоритмом. У разі використання добової норми електроенергї̈ може виникнути ситуачія, за якої увімкнутою залишиться тільки частина світильників, щзо спричинить дискомфорт для персоналу та впливатиме на продуктивність прачі співробітників. Пропонується впровадження другого незалежного каналу електропостачання з використанням газогенераторних технологій. Вироблений газ забезпечує роботу двигуна внутрішнього згорання, який обертає вал генератора.

Представлено графік прогнозованого вироблення енергї фотоелектричною системою встановленою потужністю 3,5 кBт на основі даних сонячної інсоляиії на широті м. Житомира. Також представлено графік продуктивності газогенераторної установки потужністю $5 \mathrm{\kappa Bm}$ за однозмінної роботи. Розраховано прогнозоване споживання електроенергї освітлювальною установкою протягом першого місяия року для корпусів Житомирського національного агроекологічного університету.

Представлено графік різниці між спожитою та виробленою енергією за днями тижня. Величина спожитої електрики за місяць становила 767,8 кВтггод за встановленої норми $251 \mathrm{\kappa Bm} \cdot 2 о д$. Фотоелектричними панелями та газогенераторною установкою вироблено відповідно 184,8 кВт·год та 493,2 кВт·год. Другий резервний канал живлення забезпечив більше половини потреб на освітлення навчального корпусу.

Розроблено структурну схему контролера, що реалізує спеціалізований алгоритм. Представлено графік регульованих змінних під час роботи контролера.

Застосування спеиіалізованого алгоритму дозволяє зменшити енергоспоживання установки, забезпечує можливість повноцінного використання глибокого резервування на базі фотоелектричної системи та газогенераторної установки.

Подальші дослідження спрямовані на встановлення впливу продуктивності газогенераторної установки на стійкість роботи системи двигун-генератор в умовах мінливого попиту на електроенергію та з врахуванням нестабільного значення коефічієнта потужності. Бібл. 10, рис. 9.

Ключові слова: газогенератор, система електропостачання, фотоелектрична система.

\section{THE SUBSTANTIATION OF THE ELECTRICAL POWER SUPPLY CHANNEL BASED ON THE GAS-GENERATOR INSTALLATION}

O. Sokolovskyi, candidate of technical science, Y. Yarosh, candidate of technical science, N. Tsyvenkova, candidate of technical science, S. Kukharets, doctor of technical science

Zhytomyr National Agroecological University

10008, 7 Staryi Blvd, Zhytomyr, Ukraine

A modern tendency in power production development is an aspiration to balance the whole electric power complex, to raise the consumer power supply reliability. Autonomous power supply systems take an important place in electric power industry development. They are used in aero-, sea and river ports, in hospitals, on farms, in emergency power supply systems, on defense complex objects literally everywhere where you need power and supply is distant or working intermittently.

An autonomous power supply system powered by internal combustion engines is introduced. The main converter of an engine rotation to electric power is an alternator with excitation winding on the rotor.

An algorithm is introduced according to which a controller determines the daily amount of power consumption and, accordingly to the type and time of day, performs actions by either short or ramified algorithm. In a case when the daily rate of power is depleted, an unwished situation can occur, when only some of the lighting can stay on, that can cause discomfort for employees, and can lower their productivity. A second independent power source is proposed based on gas generator technology. A generated gas feeds an internal combustion engine which turns the alternator shaft.

A diagram of predicted power production of a $3.5 \mathrm{~kW}$ photovoltaic installation is presented, based on insolation data for Zhytomyr latitude. Also, a productivity diagram for gas generator installation with a nominal power output of $5 \mathrm{~kW}$ for one shift operation is presented. A predicted power consumption for a lighting installation for the first month of the year for all buildings of Zhytomyr national agroecological university is calculated.

(C) О.Ф.Соколовський, Я.Д.Ярош, Н.М.Цивенкова, С.М.Кухарець, 2019

Відновлювана енергетика. 2019. № 1 
A diagram of difference between produced and consumed power by days is presented. A monthly amount of consumed power is $767.8 \mathrm{kWh}$ while the restricted norm is $251 \mathrm{kWh}$. Photovoltaic provided $184.8 \mathrm{kWh}$. The gas generator provided $493.2 \mathrm{kWh}$. The second reserve power supply channel provided more than a half of needed power for lighting.

A structural diagram of a controller, that performs a specialized algorithm, is developed. A diagram of variables regulated during controller operation is presented.

Implementation of the specialized algorithm can lower the installation energy consumption, provides the possibility of high-grade usage of deep reserving based on photovoltaic system and gas generator installation.

Further investigations are directed towards determining of an influence of gas generator installation productivity on operational stability of an engine-alternator system under the conditions of variable power demand and considering unstable power factor. Ref. 10, fig.9.

Keywords: gas producer, power supply system, photovoltaic system.

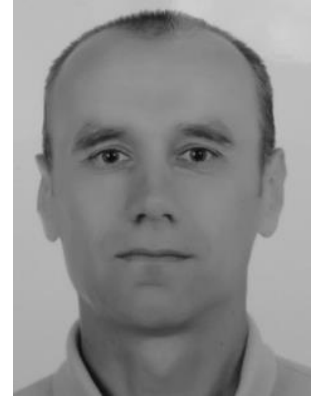

О.Ф. Соколовський O. Sokolovskyi

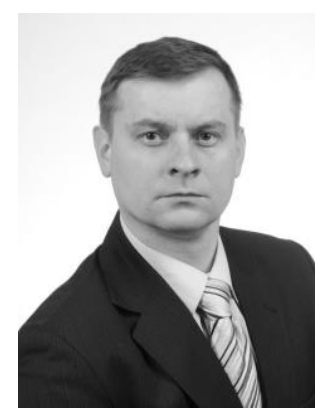

Я.Д. Ярош

Y. Yarosh

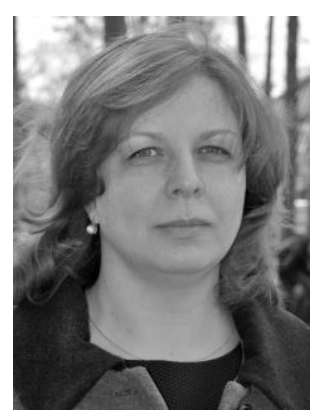

H.М. Цивенкова

N. Tsyvenkova
Відомості про автора: завідувач кафедрою електрифікації, автоматизації виробництва та інженерної екології Житомирського національного агроекологічного університету, к.т.н, доцент. Освіта: Національний технічний університет України «Київський політехнічний інститут імені Ігоря Сікорського».

Наукова сфера: біоенергетичні системи аграрного виробництва, електротехнічні системи, енергозбереження в системах автоматизованого електропривода.

Публікації: 50 публікацій, з них 32 наукові (у тому числі 26 наукових праць, опублікованих у вітчизняних і 6 у міжнародних рецензованих фахових виданнях), 2 патенти на винахід та 11 навчально-методичного характеру.

ORCID: 0000-0001-8440-7462

Контакти: +38(097) 578-77-54

e-mail: of@ukr.net

Відомості про автора: декан факультету інженерії та енергетики Житомирського національного агроекологічного університету, к.т.н., доцент кафедри процесів, машин і обладнання в агроінженерії.

Наукова сфера: біоенергетичні системи аграрного виробництва, технологічні засоби формування екологобезпечних проектів у агрохарчовій галузі.

Освіта: Тернопільський національний технічний університет імені Івана Пулюя.

Публікації: 70, з них 56 наукові (у тому числі 46 наукових праць, опублікованих у вітчизняних $\mathrm{i}$ 10 у міжнародних рецензованих фахових виданнях), 4 патенти та 14 матеріалів навчальнометодичного характеру.

ORCID: 0000-0001-6590-7058

Контакти: +38 (067) 796-24-49

e-mail: yaroslav.yarosh76@gmail.com

Відомості про автора: заступник декана з нау-

кової роботи факультету інженерії та енергетики Житомирського національного агроекологічного університету, к.т.н., доцент кафедри механіки та інженерії агроекосистем.

Освіта: Житомирський державний технологічний університет.

Наукова сфера: енергозбереження, альтернативна енергетика, біоенергетичні системи і комплекси.

Публікації: 82, з них 65 наукові (у тому числі 55 наукових праць, опублікованих у вітчизняних $\mathrm{i}$ 10 у міжнародних рецензованих фахових виданнях), 2 патенти на винахід та 18 праць навчальнометодичного характеру.

ORCID: 0000-0003-1703-4306

Контакти: +38 (050) 313-89-03

e-mail: nataliyatsyvenkova@gmail.com
Author information: head of Electrification, Automation of Production and Engineering Ecology Department (Engineering and Energetic Faculty) of Zhytomyr National Agroecological University, Ph.D, assis. professor of Mechanics and Agroecosystems Engineering Department.

Education: National Technical university of Ukraine «Igor Sikorsky Kyiv Polytechnic Institute».

Research area: bioenergy systems of agrarian production, electrical and technical engineering systems, energy saving in automated electric drive systems.

Publications: 50, including 32 scientific articles (26 scientific papers were published in Ukrainian peerreviewed journals, and 6 - in international), 2 patents and 11 educational and methodical materials.

ORCID: 0000-0001-8440-7462

Contacts: +38(097) 578-77-54

e-mail: of@ukr.net

Author information: dean of Engineering and Energetic Faculty of Zhytomyr National Agroecological University, Ph.D, assis. professor of Processes, Machinery, and Equipment in Agroengineering Department.

Education: Ternopil Ivan Puluj National Technical University.

Research area: bioenergy systems of agrarian production, technological means of forming ecologically safe projects in the sphere of agro-food industry. Publications: 70, including 56 scientific articles (46 scientific papers were published in Ukrainian peerreviewed journals, and 10 - in international),

4 patents and 14 educational and methodical materials.

ORCID: 0000-0001-6590-7058

Contacts: +38 (067) 796-24-49

e-mail: yaroslav.yarosh76@gmail.com

Author information: deputy dean in science of Engineering and Energetic Faculty of Zhytomyr National Agroecological University, Ph.D, assis. professor of the Mechanics and agroecosystems engineering Department.

Education: Zhytomyr state technological university. Research area: energy saving, alternative energy, bionergetic systems and complex.

Publications: 82, including 65 scientific articles (55 scientific papers were published in Ukrainian peerreviewed journals, and 10 - in international), 2 patents and 18 educational and methodical materials.

ORCID: 0000-0003-1703-4306

Contacts: +38 (050) 313-89-03

e-mail: nataliyatsyvenkova@gmail.com 


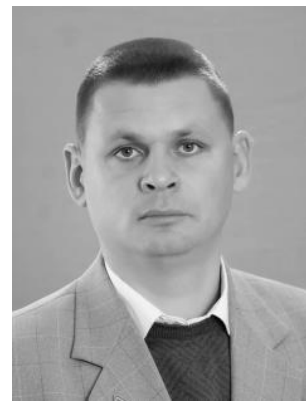

C.M. Kyхареuь

S. Kukharets
Відомості про автора: завідувач кафедрою механіки та інженерії агроекосистем Житомирського національного агроекологічного університету, д.Т.н.

Освіта: Житомирський національний агроекологічний університет.

Наукова сфера: технічна біоенергетика, технічне забезпечення агроекосистем.

Публікації: 155, з них 128 наукові (у тому числ 114 наукових праць, опублікованих у вітчизняних і 14 у міжнародних рецензованих фахових виданнях), 4 наукові монографії, 14 патентів на винахід та 27 праць навчально-методичного характеру (з них 1 підручник, 3 навчальні посібники).

Контакти: +38 (067) 665-35-48

e-mail: saveliy_76@ukr.net
ORCID: 0000-0002-5129-8746

Author information: head of the Mechanics and Agroecosystems Engineering Department (Engineering and Energetic Faculty) of Zhytomyr National Agroecological University, D.Sc, professor of the Mechanics, and Agroecosystems Engineering Department.

Education: Zhytomyr National Agroecological University.

Research area: technical biotechnology, technical support of agro-ecosystems.

Publications: 155, including 128 scientific articles (114 scientific papers were published in Ukrainian peer-reviewed journals, and 14 - in international), 4 monographs, 14 patents and 27 educational and methodical materials.

ORCID: 0000-0002-5129-8746

Contacts: +38 (067) 665-35-48

e-mail: saveliy_76@ukr.net

Перелік використаних позначень та скорочень:

$W_{Y}$ - споживання енергії від мережі централізованого електропостачання, кВт·год;

$W_{C п} \quad$ - електроенергія, спожита від фотоелектричної $L$ системи, кВт·год;

$W_{C \Gamma} \quad$ - електроенергія, спожита від газогенераторної установки, кВт·год;

$W_{T i} \quad$ - електроенергія, спожита протягом темного часу доби, кВт.год;

$W_{X м i}$ - електроенергія, спожита внаслідок хмарності, кВт.год;

$P_{C}, P_{H} \quad-$ встановлена потужність сонячних панелей та освітлювальної установки, кВт;

$P_{C H} \quad-$ потужність однісї панелі, кВт;

$T \quad$ - тривалість робочого дня, год;

$k_{C}-$ сезонний коефіцієнт сонячної системи (для літа $k_{C}=0,5$; для зими $k_{C}=0,7$ );

$k X C-$ сезонний коефіцієнт хмарності;

Ахп - величина хмарності відповідно до прогнозу погоди;

$t_{T} \quad-$ тривалість сутінок на проміжку робочого дня, год;

$t_{\Gamma}, t_{C} \quad$ - відповідно час використання на добу енергії, виробленої газогенераторною системою автономного електропостачання та час використання на добу сонячної енергії, год;

$N \quad$ - кількість робочих днів протягом місяця;

$n-$ ціле додатне число;

$Z \quad-$ кількість сонячних панелей;

$G_{\text {д }}-$ середньодобове значення сонячної інсоляції, кВТ·год/ $\mathrm{M}^{2}$;

$H-$ - інтенсивність сонячного випромінювання за якого виконують тестування сонячних панелей, кВт/м².

Вступ. Сучасною тенденцією розвитку енергетики $є$ прагнення до збалансованості енергетичного комплексу, підвищення надійності електропостачання споживачів. Важливе місце в стратегії розвитку електроенергетики займають автономні системи електропостачання. Останнім часом такі системи отримують все більше поширення майже у всіх галузях народного господарства [5]. Необхідність в автономних системах виникає там, де технічно неможливо або економічно невигідно використовувати централізоване електропоста-
$Q_{\Pi}$

$L_{\Gamma}$

$\eta д в$

$\eta \Gamma$

$E\left(n \cdot T_{0}\right)$

$E\left((n-1) \cdot T_{0}\right)$

$U_{3} \cdot\left((n+1) \cdot T_{0}\right)$

$U \cdot\left((n-1) \cdot T_{0}\right)$

$T_{0}$

$U_{d,} U_{q}$

$U_{f d}^{\prime}, U_{k d}^{\prime}$,

$U^{\prime}{ }^{\prime} q 1, U^{\prime} \mathrm{k} q 2$

$i_{d}, i_{q}$

$i_{f d}^{\prime}, i_{k d}^{\prime}, i_{k q 1}^{\prime}$ $i^{\prime}{ }^{\prime}{ }^{\prime}{ }^{2}$

$\phi_{d}, \phi_{q}$

$\phi_{f d,}^{\prime} \phi_{k d,}^{\prime}$

$\phi_{k q 1}^{\prime}, \phi_{k q 2}^{\prime}$

$R_{S}$

$R_{f d,}^{\prime} R_{k d}^{\prime}$,

$R^{\prime} R^{\prime} q, R^{\prime} q 2$
- потужність, отримана 3 м ${ }^{3}$ газу, кВт/м³

- продуктивність газогенератора за добу, $\mathrm{M}^{3} /$ добу;

- коефіцієнт корисної дії двигуна внутрішнього згорання;

- коефіцієнт корисної дії синхронного генератора;

- освітленість на поточному кроці квантування алгоритму, лк;

- освітленість на попередньому кроці квантування, лк;

- напруга завдання, встановлена системою керування, В;

- напруга завдання, що визначається персона лом на попередньому кроці квантування алгоритму, B;

- період квантування, хв;

- проекції напруг статора;

- проекції приведених напруг збудження;

- проекції струмів статора;

- проекції приведених струмів збудження;

- проекції потокозчеплення статора;

- проекції приведених потоків потокозчеплен ня ротора;

- активний опір статора;

- проекції приведених опорів ротора, де індекси змінних і параметрів позначають таке: $d$, $q$ - проекції змінних на осі $d$ і $q ; f, k$ - змінні кола збудження і демпферної обмотки. чання, наприклад, на пересувних об'єктах. Автономні системи знаходять широке застосування в промисловості, будівництві, сільському і комунальному господарствах. Вони використовуються на підприємствах, в аеро-, морських і річкових портах, в енергоблоках лікарень, у фермерських господарствах, в системах аварійного енергопостачання, на об' єктах оборонного комплексу - скрізь, де потрібна електроенергія, в той час як мережа або віддалена, або працює з перебоями.

Для отримання стабільного надходження 
енергії в автономних системах доречним буде використання газогенераторів [1, 2]. Генераторний газ використовується в якості палива для двигунів внутрішнього згоряння, газотурбінних установок, теплотехнічного обладнання та виро- бництва електроенергії $[1,2]$.

Постановка завдання. Первинним джерелом енергії в запропонованій системі (рис. 1) є газогенератор, вироблений газ якого $є$ пальним для двигуна внутрішнього згорання.

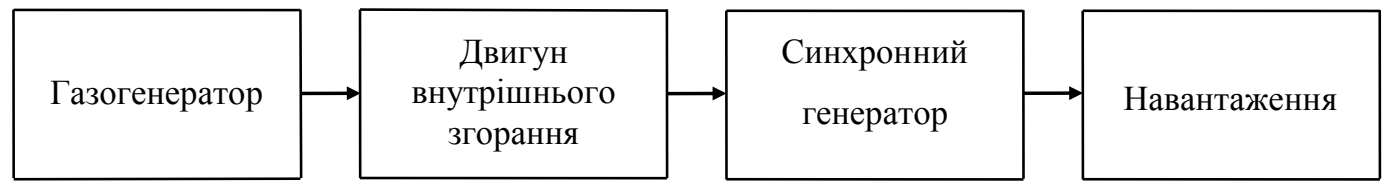

Рис. 1. Структурна схема газогенераторної системи автономного електропостачання Fig. 1. Gas generator system block diagram for autonomous power supply

Основними перетворювачами механічної енергії приводних двигунів в електричну є синхронні генератори, асинхронні генератори та генератори постійного струму. Застосування асинхронних генераторів обмежується нестабільністю напруги та частоти у разі зміни параметрів навантаження та вимагає впровадження складних систем керування збудженням [4]. Використання колекторних генераторів обмежене недостатнім поширенням приладів постійного струму або ж вимагає застосування інверторів для отримання змінної напруги [6]. Синхронні генератори дозволяють отримувати якісну енергію змінного струму фіксованої частоти при зміні навантаження в межах номінальної потужності [3]. Тому для запропонованої системи автономного електропостачання обрано електромеханічний перетворювач змінного струму з обмоткою збудження, розташованою на роторі.

Одним зі способів зменшення витрат на освітлення є застосування автономних систем на базі фотоелектричних панелей, що в поєднанні зі світлодіодною технікою дозволяє отримувати значну економію електроенергії. Для реалізації таких систем необхідно впровадити такі рішення [9]:

- застосовувати в якості пристроїв комутації імпульсних вимикачів, що дозволить здійснювати централізоване керування освітленням автоматично та в ручному режимі;

- встановити датчики освітленості, датчики присутності в робочих приміщеннях, датчики положення жалюзі;

- періодично вимикати світло в автоматичному режимі в неробочий час;

- застосувати системи сонячного електропостачання $з$ автономними інверторами типу off-grid для часткового покриття потреб на освітлення;

- впровадити світлодіодне освітлення офісу (для зменшення вартості реконструкції системи пропонується заміна люмінесцентних ламп на світлодіодні зі збереженням встановлених світильників);
- зонально керувати освітленням 3 метою створення необхідної освітленості в окремих частинах приміщень;

- запровадити добові норми витрат електроенергії з урахуванням тривалості робочого дня, тривалості сутінок відповідно до астрономічних даних, хмарності відповідно до прогнозу погоди;

- централізовано керувати системою від програмованого логічного контролера.

Відповідно до розробленого алгоритму [9] на початку циклу контролер визначає добову норму споживання електроенергії та, відповідно до типу дня і часу доби, виконує дії за коротким чи розгалуженим алгоритмом. На проміжку неробочого часу (18:00-08:00) контролер виконує періодичне вимикання світла через кожні дві години. Цю саму процедуру контролер виконує у вихідні дні. На інтервалі 08:00-18:00 в робочий день відповідно до сигналів датчиків присутності, освітленості та положення жалюзі з урахуванням добового залишку електроенергії забезпечується живлення системи освітлення від мережі централізованого електропостачання або від акумуляторних батарей фотоелектричної системи. У разі використання добової норми електроенергії може виникнути ситуація, за якої увімкнутою залишиться тільки частина світильників, що спричинить дискомфорт для персоналу та впливатиме на продуктивність праці співробітників.

Пропонується впровадження другого незалежного каналу електропостачання на основі газогенераторної установки [2]. Вироблений газ буде забезпечувати роботу двигуна внутрішнього згорання, який у свою чергу обертатиме вал генератора. У більшості випадків для вироблення електроенергії в автономних системах електропостачання 3 електромеханічними перетворювачами застосовують синхронні та асинхронні генератори напругою 220/380 B.

Виклад основного матеріалу. В мобільних електростанціях для нормальної роботи генера- 
тора частота обертання привідного двигуна підтримується на рівні 3000 об/хв. В умовах нестабільної продуктивності газогенератора та коливання величини навантаження, що викликатиме зміну обертів генератора та, як наслідок, погіршення якості виробленої електроенергії, найбільш прийнятним буде схемне рішення: газогенератор двигун внутрішнього згорання - синхронний генератор - контролер зарядження - акумуляторні батареї - інвертор 220/380 В. Застосування такої схеми дозволить отримати додаткове резервне джерело та уникнути вимуше- ного зменшення рівня освітлення приміщень навчального корпусу у випадку розрядження акумуляторних батарей фотоелектричної системи.

Алгоритм роботи контролера (рис. 2) передбачатиме порівняння стану зарядження акумуляторних батарей 3 подальшим вибором основного каналу живлення в умовах вичерпання добової норми витрат електроенергії на освітлення корпусу. У разі недостатнього рівня зарядження батарей фотоелектричної системи $\left(\mathrm{U}_{\Gamma}>\mathrm{U}_{\mathrm{C}}\right)$ в роботу вступає вузол на основі газогенераторної установки.

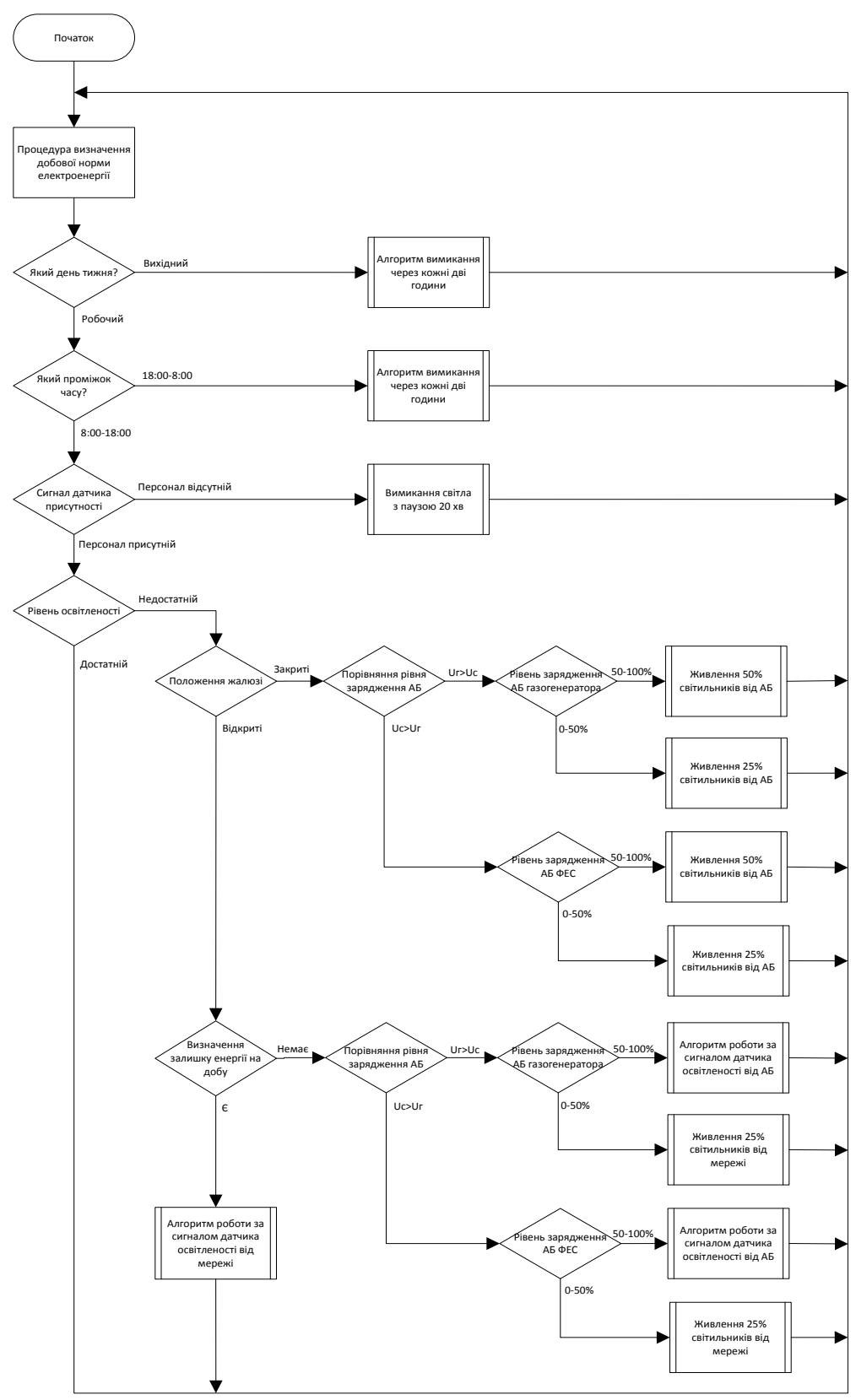

Рис. 2. Алгоритм роботи контролера

Fig. 2. Algorithm of controller operation 
Енергозберігаючі властивості розробленої мережі забезпечуються: у нормальному режимі за рахунок використання датчиків присутності, освітленості та періодичного вимикання світла в неробочий час; в екстремальному режимі (у разі затемнення вікон) за рахунок зниження рівня штучного освітлення та спонукання персоналу до використання природного освітлення; в ощадному режимі (у випадку вичерпання добової норми) за рахунок вмикання відповідного алгоритму; використанням фотоелектричної системи та газогенераторної установки.

Величина електроенергії, яку споживає запропонована система за добу:

$$
\begin{gathered}
W_{\Pi}\left(P_{H}, P_{C}, P_{\Gamma}, T, k_{X C}, A_{X I}, t_{T}, t_{C}, t_{\Gamma}\right)= \\
=W_{y}\left(P_{H}, T, t_{T}, k_{X C}, A_{X I}\right)+ \\
+W_{C I}\left(P_{C}, t_{C}\right)+W_{C \Gamma}\left(P_{\Gamma}, t_{\Gamma}\right) .
\end{gathered}
$$

Сумарне прогнозоване споживання електроенергії за добу:

$$
\begin{gathered}
W_{y_{i}}=W_{T i}+W_{X M i} . \\
W_{T i}=P_{H} \cdot t_{T i} . \\
W_{X M i}=P_{H} \cdot k_{X C} \cdot T \cdot N \cdot \frac{A_{X I T i}}{\sum_{1}^{N} A_{X I I i}} .
\end{gathered}
$$

Рекомендується прийняти $k_{X C}=0,3$ для зимових місяців, $k_{X C}=0,2$ - для весни та осені, $k_{X C}=0,1-$ для літа. 3 метою врахування витрат електроенергії у сонячний день через затемнення вікон приймемо для зими $A_{X I}=0$, для весни та осені $-A_{X I}=0,5$, для літа $-A_{X \Pi}=1$. Визначення хмарності здійснюється відповідно до прогнозу на погодних сайтах [8] за чотирибальною шкалою.

Величина електроенергії, яку може виробити сонячна система електропостачання за добу, кВт·год:

$$
W_{\text {СД }}=\frac{Z \cdot k_{C} \cdot P_{C H} \cdot G_{\text {Д }}}{H} .
$$

Кількість електроенергії, виробленої газогенераторною установкою протягом доби:

$$
W_{\text {Гд }}=Q_{\Pi} \cdot L_{\Gamma} \cdot \eta_{\text {ДВ }} \cdot \eta_{\Gamma} \cdot
$$

На рис. 3 зображено: графік прогнозованого вироблення енергії фотоелектричною системою $W_{C M}$ встановленою потужністю 3,5 кВт на основі даних сонячної інсоляції [10] на широті м. Житомира 3 урахуванням середньостатистичних показників хмарності у січні 2018 року; гра- фік продуктивності газогенераторної установки $W_{\Gamma м}$ потужністю 5 кВт за однозмінної роботи обслуговуючого персоналу; графік прогнозованого споживання електроенергії освітлювальною установкою $W_{O M}$ протягом першого місяця року для забезпечення потреб навчального корпусу Житомирського національного агроекологічного університету.

Добова норма витрат для кожного із 22 робочих днів зображена на графіку $W_{H M}$.

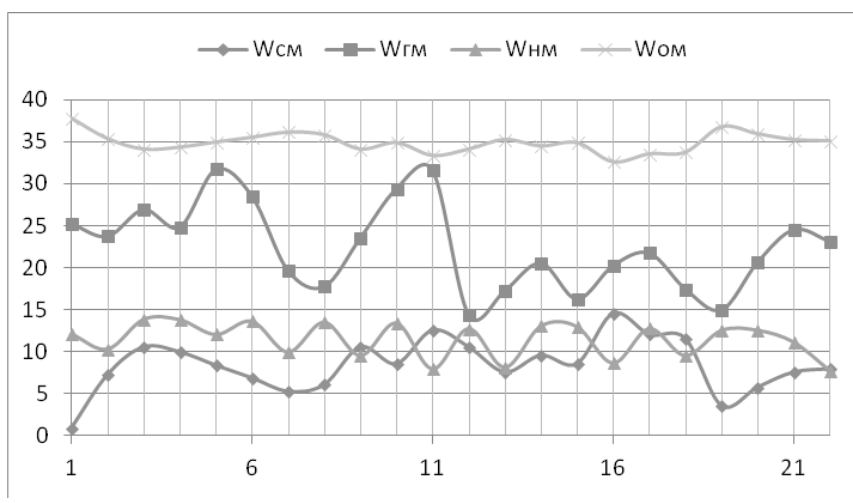

Рис 3. Графік прогнозованого вироблення енергії фотоелектричною системою

Fig. 3. Graph of the projected energy generation by a photoelectric system

На рис. 4 представлено графічну залежність, яка відображає різницю між спожитою та виробленою енергією за днями тижня. Найбільший дисбаланс за абсолютними показниками спостерігався на 3-й, 5-й, 10-й та 11-й робочі дні тижня. Лише три дні тижня характеризуються дефіцитом енергії, яка має забезпечуватися двома допоміжними каналами електропостачання.

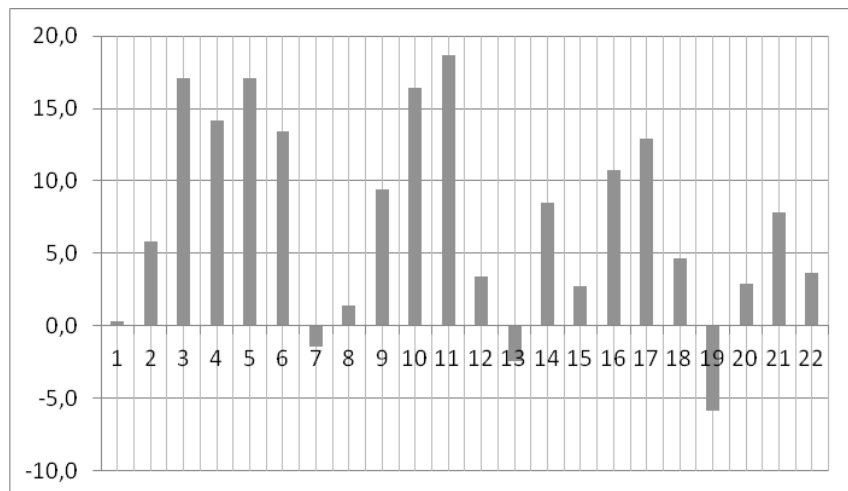

Рис. 4. Різниця між спожитою та виробленою енергією за днями тижня

Fig. 4. Difference between consumption and produced energy by days of the week

Величина спожитої електрики за місяць становила 767,8 кВт-год за встановленої норми 251 кВт·год. Фотоелектричними панелями та газогенераторною установкою вироблено відповідно 184,8 кВт·год та 493,2 кВт.год. Другий резер- 
вний канал живлення забезпечив більше половини потреб на освітлення навчального корпусу.

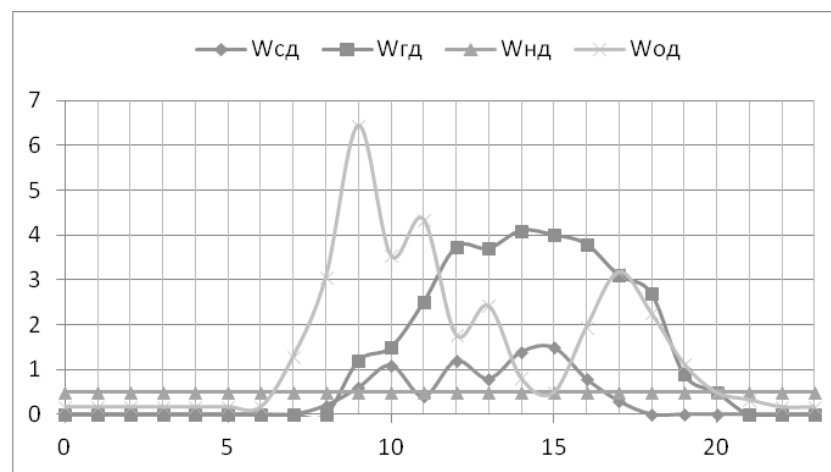

Рис. 5. Енергетичні показники установки протягом доби

Fig. 5. Energy indicators of the installation during the day

На рис. 5 зображено: графік вироблення енергії $W_{C Д}$ фотоелектричною системою протягом доби; графік продуктивності газогенераторної

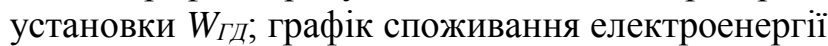
освітлювальною установкою $W_{\text {од за той самий }}$

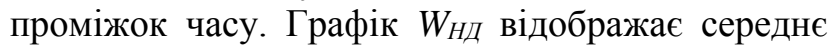
споживання електроенергії освітлювальною установкою відповідно до встановленої норми. На окремих проміжках часу ділянки графіків споживання та вироблення електричної енергії мають протилежні тренди. Це пов'язано 3 мінливістю освітлення фотоелектричних панелей та нестабільною продуктивністю газогенераторної установки, а також значним зменшенням споживання енергії у денний час, коли сонячні модулі забезпечують найбільший коефіцієнт корисної дії.

У разі низького рівня зарядження акумуляторних батарей одночасно за двома каналами можливе виникнення ситуації, коли освітленість приміщень не буде відповідати встановленим вимогам. Пропонується застосування спеціалізованого алгоритму, за якого система керування зменшуватиме освітленість у разі вичерпання добової норми електроенергії незалежно від рівня зарядження акумуляторних батарей. При цьому зберігається принцип пріоритетності вибору каналу живлення за ознакою стану електрохімічних джерел енергії. Рівняння, що реалізує алгоритм:

$$
U_{3}\left((n+1) T_{0}\right)=\frac{E\left(n T_{0}\right)}{E\left((n-1) T_{0}\right)} U\left((n-1) T_{0}\right),
$$

Структурна схема контролера, що реалізує спеціалізований алгоритм, зображена на рис. 6.

$3 E$

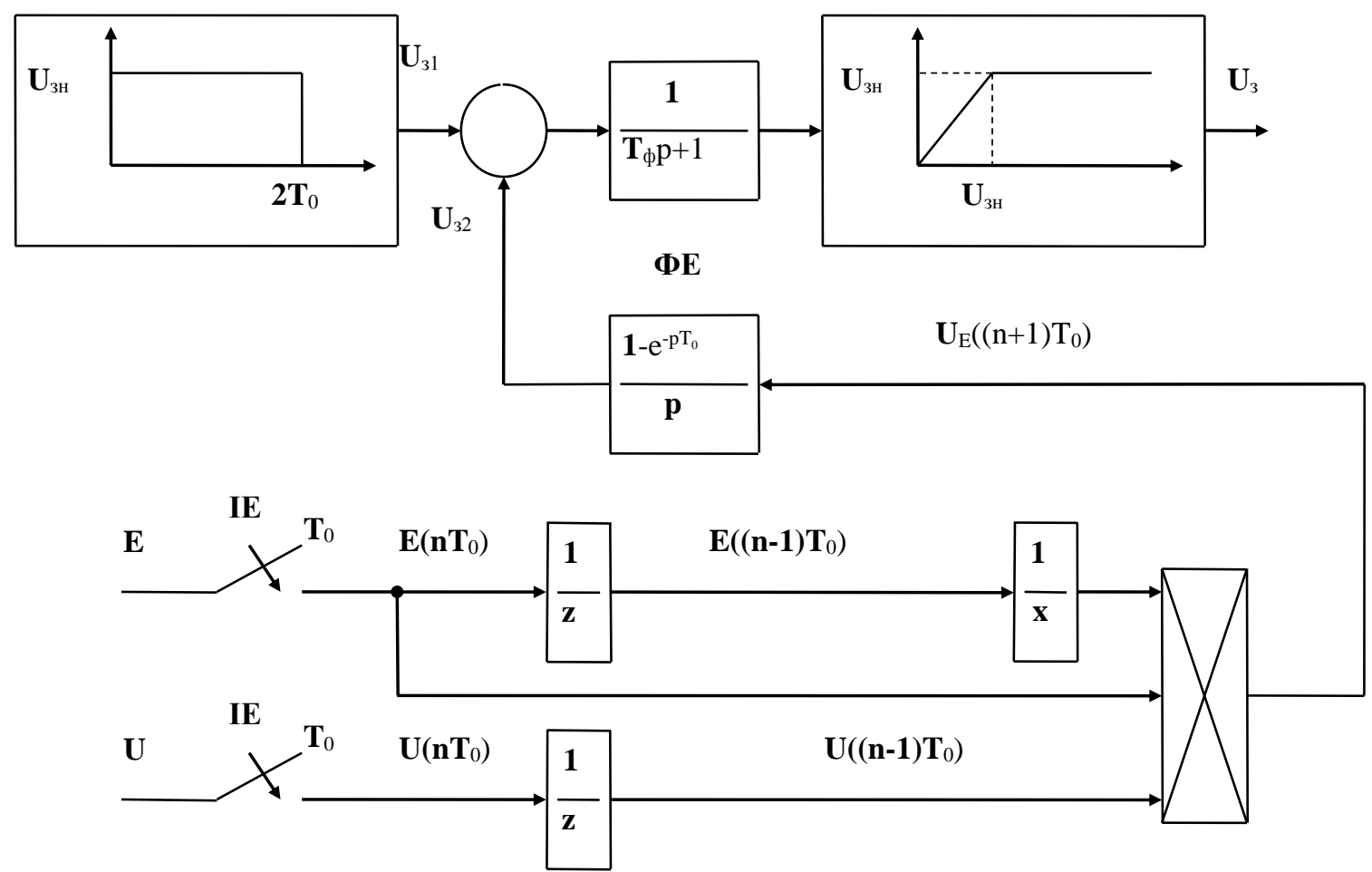

Рис. 6. Структурна схема реалізації спеціалізованого алгоритму

Fig. 6. Block diagram of specialized algorithm implementation

Задаючий елемент ЗЕ формує напругу завдання $U_{31}$, яка відповідає номінальному значенню освітленості і утримується протягом пе- ріоду часу $2 T_{0}$ під час вмикання системи освітлення. Період квантування $T_{0}$ повинен перевищувати час перехідних процесів, викликаних у 
системі зміною напруги завдання. Інформація про освітленість надходить у фіксовані моменти часу $n T_{0}$ за допомогою імпульсних елементів IE. Ланки $1 / z$ реалізують затримку сигналів на один фіксований часовий крок. Формуючий елемент $\Phi Е$ забезпечує формування сигналу завдання освітленості після вмикання системи. Ланка $1 / x$ реалізує обернено-пропорційну залежність. Через нульові початкові умови роботи системи $(E=0, U=0)$ напруга $U_{32}$ буде дорівнювати нулю протягом $2 T_{0}$. Для зменшення стрибків струмів під час перехідних процесів напруга завдання подається через аперіодичний фільтр зі сталою часу $T_{\phi}$.

Початковий режим визначається освітленістю $E=150$ лк (рис. 7). У момент часу $4 T_{0}$ формується сигнал керування на виході спеціалізованого регулятора $U_{3}\left((n+1) T_{0}\right) \quad 3$ урахуванням: $E\left(n \cdot T_{0}\right)=120 л \kappa ; \quad E \cdot(n-1) \cdot T_{0}=150 л \kappa ; \quad U\left(n \cdot T_{0}\right)=7 \mathrm{~B} ;$ $U\left((n-1) \cdot T_{0}\right)=10 B$. При цьому напруга завдання зменшується з $10 \mathrm{~B}$ до 7,3 В. Далі система реагує на потреби споживачів. Збільшення сигналу завдання з боку персоналу від $3 B$ до $9 B$ призведе до зростання освітленості у момент часу $7 T_{0}$. У випадку відповідності освітленості приміщення сигналу завдання на вході системи, напруга завдання на кожному наступному кроці квантування змінювалася б пропорційно встановленому завданню персоналом на двох сусідніх кроках квантування алгоритму. Але освітленість приміщень залежить від багатьох факторів, що суттєво впливає на форму графіка вихідної напруги регулятора. Для уникнення різких коливань освітленості рекомендується прийняти період квантування $T_{0}=15 \times 8$.

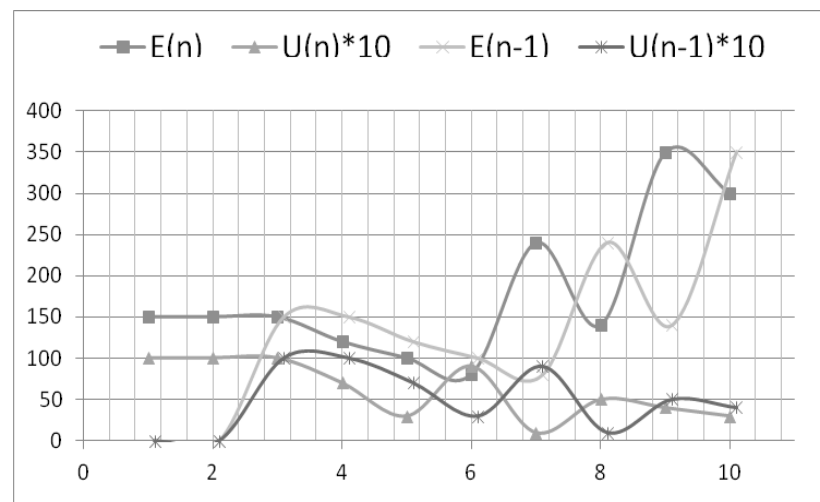

Рис. 7. Графіки регульованих змінних під час роботи спеціалізованого регулятора

Fig. 7. Diagram of regulated variables during the operation time of a specialized regulator

Проведемо дослідження автономної системи електропостачаня за допомогою програми Simulink, яка є додатком до пакета MATLAB [7]. Для моделювання перехідних процесів скористаємося блоком Synchronous Machine PU
Fundamental бібліотеки SimPowerSystems. Блок є моделлю класичної синхронної машини 3 демпферною обмоткою. Електрична частина синхронного генератора описується системою диференційних рівнянь шостого порядку (8) в системі координат, пов'язаною з ротором [6].

Порти моделі $є$ виводами статорної обмотки машини. Сигнал, що відповідає механічній потужності на валу подається на вхідний порт $P m$, а на вхідний порт $V f$ подається еквівалент напруги обмотки збудження. На вихідному порту $m \_p u$ формується векторний сигнал, який містить 16 змінних: 1-3 - струми обмотки статора $i_{s a}, i_{s b}, i_{s c}$; 4-5 - проекції струмів статора $i_{d}, i_{q} ; 6-8$ - струм збудження $i_{f d}$ та проекції струмів демпферної обмотки $i_{k d}, i_{k q} ; 9-10$ - проекції потоку намагнічування $\phi_{m}, \phi_{m q} ; 11-12$ - проекції напруг статора $U_{d}, U_{q} ; 13$ - відхилення ротора $\Delta \theta, 14$ - швидкість ротора $\omega_{r} ; 15$ - електромагнітна потужність $P_{\theta} ; 16$ - відхилення швидкості ротора $\Delta \omega$.

$$
\begin{aligned}
& U_{d}=R_{s} i_{d}+\frac{d \varphi_{d}}{d t}-\omega_{R} \varphi_{q}, \\
& U_{q}=R_{s} i_{q}+\frac{d \varphi_{q}}{d t}-\omega_{R} \varphi_{d}, \\
& U_{f d}^{\prime}=R_{f d}^{\prime} i_{f d}^{\prime}+\frac{d \varphi_{f d}^{\prime}}{d t}, \\
& U_{k d}^{\prime}=R_{k d}^{\prime} i_{k d}^{\prime}+\frac{d \varphi_{k d}^{\prime}}{d t}, \\
& U_{k q 1}^{\prime}=R_{k q 1}^{\prime} i_{k q 1}^{\prime}+\frac{d \varphi_{k q 1}^{\prime}}{d t}, \\
& U_{k q 2}^{\prime}=R_{k d 2}^{\prime} i_{k q 2}^{\prime}+\frac{d \varphi_{k q 2}^{\prime}}{d t}
\end{aligned}
$$

Для зручності отримання вихідних величин в Simulink передбачено блок Machines Measurement Demux. Стабілізація напруги на виводах машини у разі зміни навантаження здійснюється колом зворотного зв'язку 3 використанням блоку Excitation System. Блок є моделлю системи збудження для синхронної машини, що дозволяє регулювати напругу на затискачах у разі генераторного режиму. За основу блоку взятий збудник без врахування насичення магнітного кола. На перший вхід блоку (vref) подається необхідне значення напруги на затискачах статора. На другий $(v d)$ і третій $(v q)$ входи подаються поточні значення проекцій напруг статора на осі $d$ i $q$. Четвертий вхід може бути використаний для створення контуру стабілізації потужності. Всі вхідні змінні та вихідна змінна мають розмірність відносних одиниць $p u$.

На рис. 8 показана схема для досліджень автономної системи електропостачання на базі синхронного генератора із чотириполюсним рото- 
ром та демпферними обмотками. Дані генератора [3]: $\quad \mathrm{P}_{\text {ном }}=5 \mathrm{\kappa BT;} \quad \mathrm{n}_{\text {ном }}=3000$ об $/ \mathrm{xB} ; \quad \mathrm{U}_{\text {ном }}=380 \mathrm{~B}$; $\mathrm{I}_{\text {ном }}=9$ A.

На рис. 9а зображено графічні залежності вихідної напруги, на рис. 9б - графічна залежність струму у разі підключення трифазного симетричного навантаження. Пуск генераторної установки здійснюється 3 навантаженням, що відповідає лінійному струму 3,8 А. Далі в три етапи через кожні 0,4 с підключалася наступна секція трифазного симетричного опору, що збільшило струм до 5,7 А. Тривалість перехідних процесів при зміні навантаження не перевищувала 0,2 с. Моделювання проводилося 3 урахуванням сталої частоти обертання привідного двигуна при зміні навантаження.

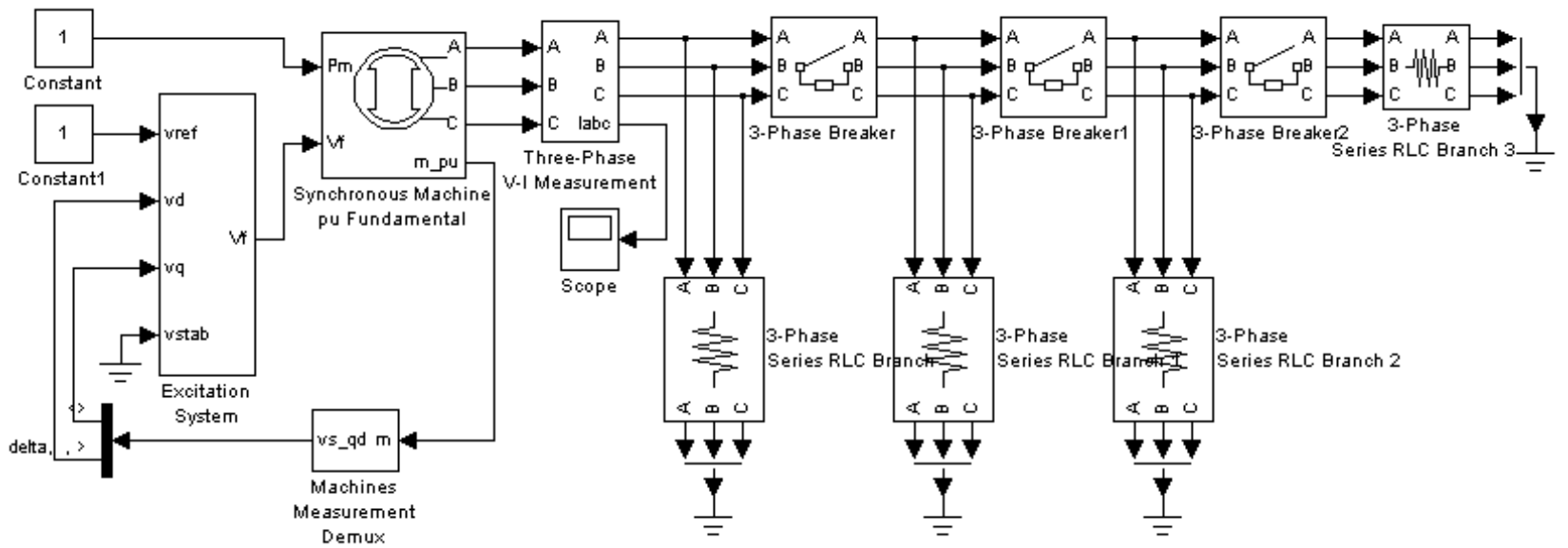

Рис. 8. Схема для дослідження системи автономного електропостачання

Fig. 8. Scheme for research of autonomous electric power supply system

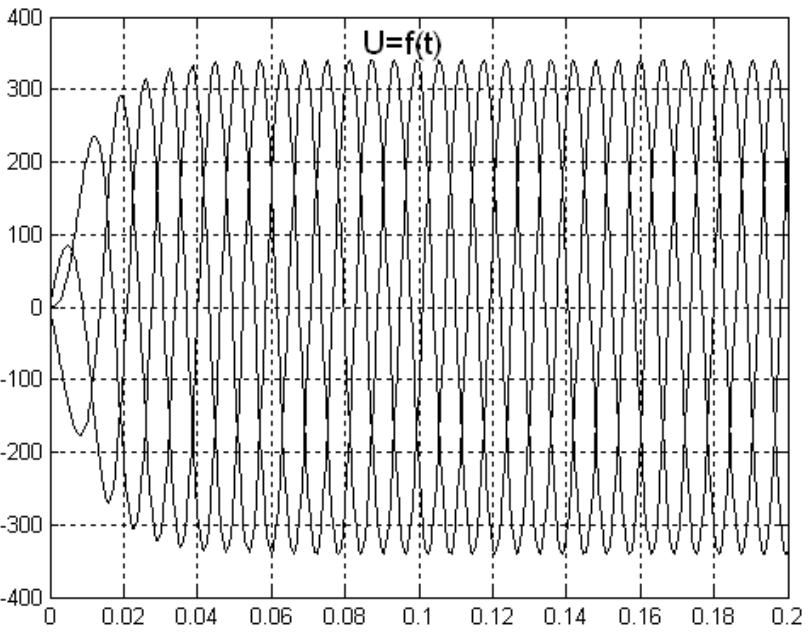

a)

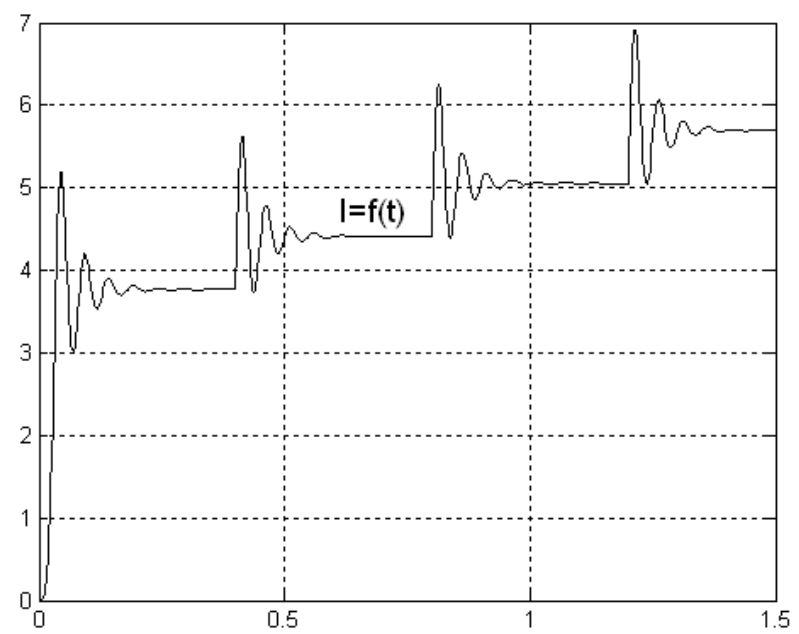

б)

Рис. 9. Результати досліджень системи автономного електропостачання

Fig. 9. Results of the research of autonomous electric power supply system

Введення додаткового каналу на основі газогенераторної системи автономного електропостачання зменшує ймовірність обмеження щодо якості освітлення приміщень навчального корпусу та водночас зберігає функцію енергоощадного виховання персоналу.

Висновки. 1. Застосування спеціалізованого алгоритму дозволяє зменшити енергоспоживання установки, забезпечує можливість повноцінного використання глибокого резервування на базі фотоелектричної системи та газогенераторної установки.

2. Вироблення необхідної кількості енергії, запропонованою системою електроживлення, залежить від продуктивності газогенераторної установки, що вимагає ретельного узгодження встановлених потужностей елементів силового каналу. Вихідна частота визначається швидкістю обертання вала генератора, напруга - струмом ротора. Тому привідний двигун і система збу- 
дження генератора повинні бути обладнані відповідними регуляторами для стабілізації обертів та напруги у випадку зміни величини та характеру навантаження. У разі застосування автономної системи для живлення обчислювальних комплексів необхідно враховувати дію поздовжньої реакції якоря, яка викликана навантаженням ємнісного характеру. Вимоги до автоматизації газогенераторної електростанції можуть бути знижені у випадку живлення нагрівальних установок (без електронних термостатів) та освітлювальних установок. Навантаження мережі електричними двигунами призведе до вимушеного збільшення встановленої потужності автономної системи електропостачання через значні пускові струми електромеханічних перетворювачів.

3. Подальші дослідження рекомендується спрямувати на встановлення впливу продуктивності газогенераторної установки на стійкість роботи системи двигун-генератор в умовах мінливого попиту на електроенергію та з урахуванням нестабільного значення коефіцієнта потужності.

1. Perez.P., Machin E.B., Pedroso D.T., Roberts J.J. , Antunes J.S., Silveira J.L. Biomass Gasification for Combined Heat and Power Generation in the Cuban Context. Energetic and Economic Analysis. Applied Thermal Engineering. 2015. Vol. 90. Pp. 1-12. URL: https://doi.org/10.1016/j.applthermaleng.2015.06.095

2. Tsyvenkova N.M., Golubenko A.A., Kukharets S.M. Biletsky V.R. The research of downdraft gas producer heat productivity on straw. Proceedings of International symposium .ISB-INMA TEH Agricultural and Mechanical Engineering. October 27-29. Bucharest. Romania. 2016. Pp. 83-91.

3. Бєлікова Л.Я., Шевченко В.П. Електричні машини: навч. посіб. для студ. вищ. навч. закладів. Одеса. Наука i техніка. 2012. $480 \mathrm{c.}$

4. Зачепа Ю.В.

Автономные

системы электроснабжения на базе асинхронных генераторов, основные требования и структура. Електромеханічні i енергозберігаючі системи: щоквартальний наукововиробничий. 2010. №2. С. 32-40.

5. Козирський В.В., Каплун В.В., Волошин С.М. Електропостачання агропромислового комплексу. К. Аграрна освіта $2011.448 \mathrm{c}$.

6. Копылов И.П., Клоков Б.К. Справочник по электрическим машинам. М. Энергоатомиздат. 1989. $688 \mathrm{c}$.

7. Островерхов М.Я., Пижов В.М. Моделювання електромеханічних систем в Simulink: навч. посібник для студ вищ. навч. закладів. К. Стилос 2008. 528 с.

8. Погода на місяць. URL: https://www.gismeteo.ua/ua/ (дата звернення: 17.01.2018)

9. Соколовський О.Ф., Соколовська Л.М. Енергозберігаюче керування освітлювальною установкою. Вісник Житомирського національного агроекологічного університету. 2017. Вип. 1(58). Т.1. С. 243-302.

10. Сонячний календар у Житомирі на січень 2018 року. URL: http://ua.365.wiki/world/ukraine/zhytomyr/ sun/calendar/january/ (дата звернення: 21.05.2018)

\section{ОБОСНОВАНИЕ КАНАЛА ЭЛЕКТРОСНАБЖЕНИЯ НА ОСНОВЕ ГАЗОГЕНЕРАТОРНОЙ УСТАНОВКИ}

О.Ф. Соколовский, канд. техн. наук, Я.Д. Ярош, канд. техн.наук, Н.М. Цивенкова, канд. техн. наук, С.М. Кухарец, докт. техн. наук

Житомирский национальный агроэкологический университет 10008 Старый бульвар, 7 г. Житомир

Современной тенденцией развития энергетики является стремление к сбалансированности энергетического комплекса, повышению надежности электроснабжения потребителей. Важное место в стратегии развития электроэнергетики занимают автономные системы электроснабжения. Они используются на предприятиях, в аэро-, морских и речных портах, в энергоблоках больнии, в фермерских хозяйствах, в системах аварийного энергоснабжения, на объектах оборонного комплекса - везде, где требуется электроэнергия, а сеть или удаленная, или работает с перебоями.

Представлено автономную систему энергоснабжения с двигателями внутреннего сгорания. Основным преобразователем механической энергии приводных двигателей в электрическую является электромеханический преобразователь переменного тока с обмоткой возбуждения, расположенной на роторе.

Представлен алгоритм, согласно которому в начале цикла контроллер определяет суточную норму потребления электроэнергии и, соответственно типу дня и времени суток, выполняет действия по короткому или разветвленному алгоритму. При использовании суточной нормы электроэнергии может возникнуть ситуачия, при которой включенными останутся только часть светильников, что вызовет дискомфорт для персонала и повлияет на производительность труда сотрудников. Предлагается внедрение второго независимого канала электроснабжения с использованием газогенераторных технологий. Произведенный газ обеспечивает работу двигателя внутреннего сгорания, который вращает вал генератора.

Представлено график прогнозируемой выработки энергии фотоэлектрической системой установленной мощностью 3,5 кBm на основе данных солнечной инсоляции на широте г. Житомира. Также представлено график производительности газогенераторной установки мощностью $5 \kappa \mathrm{Bm} \mathrm{npи}$ односменной работе. Рассчитано прогнозируемое потребление электроэнергии осветительной установкой в течение первого месяиа года для корпусов Житомирского начионального агроэкологического университета.

Представлено график разницы между потребленной и выработанной энергией по дням недели. Величина потребляемого электричества за месяч составила 767,8 кВт.ч при установленной норме 251 кВm·ч. Фотоэлектрическими панелями и газогенераторной установкой произведено соответственно 184,8 кBm·ч и 493,2 кBm·ч. Второй резервный канал питания обеспечил более половины потребностей на освещение учебного корпуса.

Разработана структурная схема контроллера, которая реализует специиализированный алгоритм. Представлен график регулируемых переменных во время работы контроллера.

Применение специиализированного алгоритма позволяет уменьшить энергопотребление установки, обеспечивает возможность полноценного использования глубокого резервирования на базе фотоэлектрической системы и газогенераторной установки. 
Дальнейшие исследования направлены на установление влияния производительности газогенераторной установки на устойчивость работы системы двигатель-генератор в условиях меняющегося спроса на электроэнергию и с учетом нестабильного значение коэффициента мощности. Библ. 10, рис. 9.

Ключевые слова: газогенератор, система электроснабжения, фотоэлектрическая система.

\section{REFERENCES}

1.Perez N.P., Machin E.B., Pedroso D.T., Roberts J.J., Antunes J.S., Silveira J.L. Biomass Gasification for Combined Heat and Power Generation in the Cuban Context. Energetic and Economic Analysis. Applied Thermal Engineering. 2015. Vol. 90. Pp. 1-12. Retrived from https://doi.org/10.1016/j.applthermaleng.2015.06.095 [in English].

2. Tsyvenkova N.M., Golubenko A.A., Kukharets S.M., Biletsky V.R. The research of downdraft gas producer heat productivity on straw. Proceedings of International symposium, ISB-INMA TEH Agricultural and Mechanical Engineering, October 27-29. Bucharest. Romania. Pp. 83-91. [in English].

3.Byelikova L.YA. Elektrychni mashyny: navch. posib. dlya stud. vyshch. navch. Zakladiv. [Electric machines: a textbook for students at higher educational institutions]. Odesa. Nauka i tekhnika. 2012. 480 p. [in Ukrainian].

4. Zachepa YU.V. Avtonomnye systemy elektrosnabzhenyy a na baze asynkhronnykh heneratorov, osnovnye trebovanyya y struktura. [Independent power supply systems based on asynchronous generators, basic requirements and structure]. Electromechanical and energy saving systems quarterly scientific and production. 2010. No.2. Pp. 32-40. [in Ukrainian].

5. Kozyrskyy V.V., Kaplun V.V., Voloshyn S.M. Elektropostachannya ahropromyslovoho kompleksu. [Power supply for agro-industrial complex]. Kiev. Ahrarna osvita. 2011. [in Ukrainian].

6. Kopylov I.P., Klokov B.K. Spravochnik po elektricheskim mashinam. [Reference book on electrical machines]. Moscow. Energoatomizdat. 1989. [in Russian].

7. Ostroverkhov M.YA., Pyzhov V.M. Modelyuvannya elektromekhanichnykh system v Simulink: navch. posibnyk dlya stud. vyshch. navch. zakladiv [Modeling of electromechanical systems in Simulink: a textbook for students at higher educational institutions]. Kiev. Stylos. 2008. [in Ukrainian].

8. Weather for a month. Retrived from https://www.gismeteo.ua/ua/ (application date: 17/01/2018) [in Ukrainian].

9. Sokolovskyy O.F., Sokolovska L.M. Enerhozberihayuche keruvannya osvitlyuvalnoyu ustanovkoyu. [Energy saving management of lighting equipment]. Visnyk Zhytomyrskoho natsionalnoho ahroekolohichnoho universytetu. 2017). No. 1(58). vol.1. Pp. 243302. [in Ukrainian].

10. Sonyachnyy kalendar u Zhytomyre na sichen' 2018 roku. [Zhytomyr region solar calendar for January 2018.] Retrived from http://ua.365.wiki/world/ukraine/zhytomyr/sun/calendar/ january/ (Applying Date: May 21, 2018). [in Ukrainian].

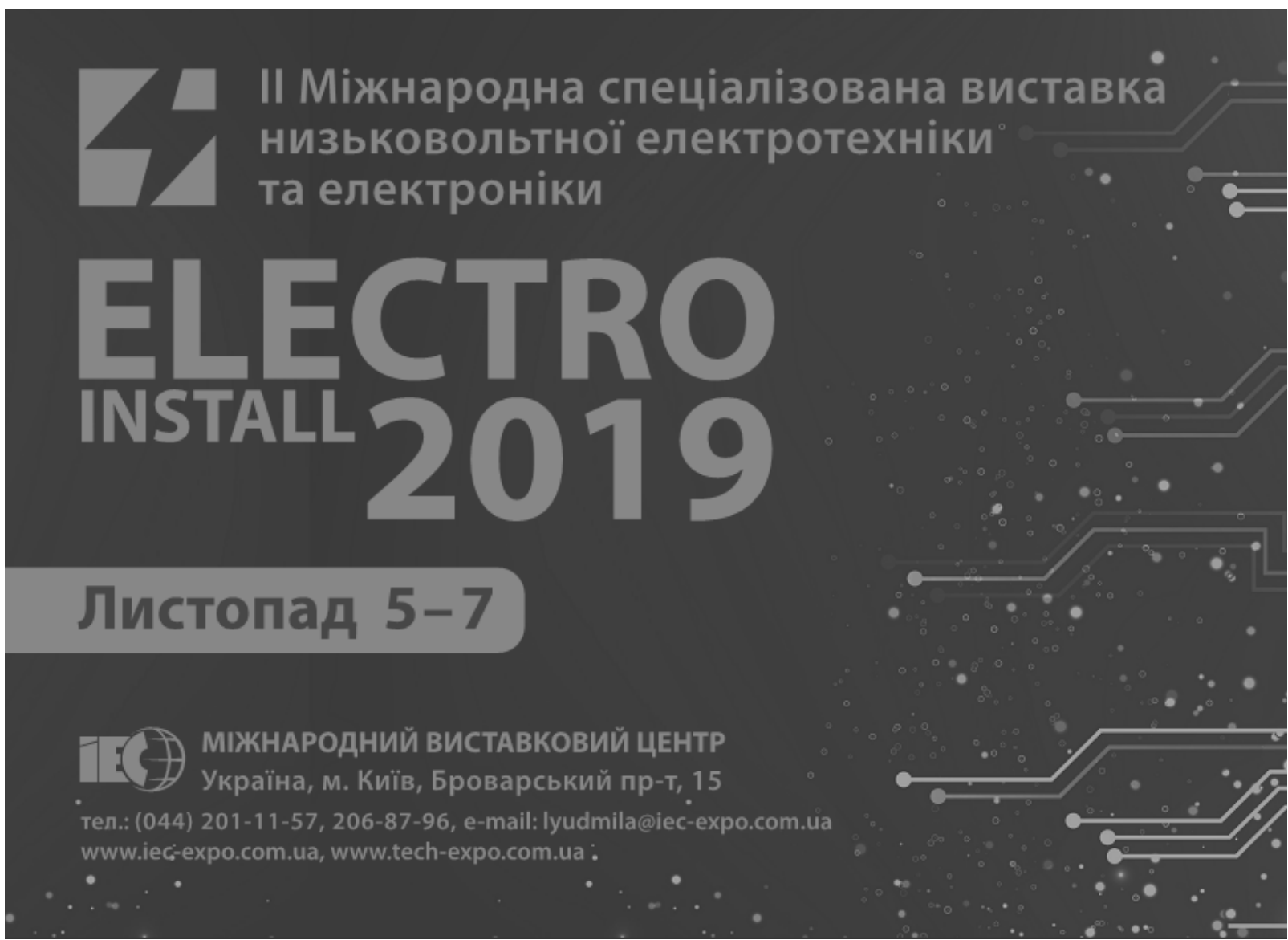

